\title{
CONFLITOS E INTERESSES ATLÂNTICOS NA CAPITANIA DE ANGOLA: O GOVERNO DE JOÃO FERNANDES VIEIRA, 1658 A 1661
}

\author{
Leandro Nascimento de Souza ${ }^{1}$
}

\begin{abstract}
RESUMO
O principal objetivo deste artigo é analisar as ações de João Fernandes Vieira como governador da capitania de Angola, no período de 1658 a 1661. E de como sua gestão estava relacionada aos seus interesses na produção açucareira e tráfico de escravizados nas capitanias de Pernambuco e Paraíba. Através de uma historiografia clássica, de manuscritos do Arquivo Histórico Ultramarino, da documentação publicada pelo padre Antonio Brásio, na Monumenta Missionária Africana, pretende-se analisar os conflitos e negociações que aconteceram nesse contexto, os jogos de poder e de como influenciaram os interesses lusitanos no Atlântico da segunda metade do século XVII.
\end{abstract}

Palavras-chave: Administração portuguesa. História de Angola. Tráfico Atlântico.

\section{ABSTRACT}

The main objective of this article is to analyze the actions of João Fernandes Vieira as governor of the captaincy of Angola, from 1658 to 1661. And how his management was related to his interests in the sugar production and trafficking of slaves in the captaincies of Pernambuco and Paraíba. Through a classic historiography of manuscripts from the Overseas Historical Archive of the documentation published by Father Antonio Brásio at the African Missionary Monument, the aim is to analyze the conflicts and negotiations that took place in that context, the power games and how they influenced the interests of Lusitanians In the second half of the 17th century.

Keywords: Portuguese administration. History of Angola. Atlantic Traffic.

\section{Introdução: A Capitania de Pernambuco e os interesses em Angola}

Pernambuco restaurado pelos colonos lusos em 1654 teve um problema agravante na questão econômica. A produção açucareira passou a sofrer a concorrência do mercado internacional, do açúcar produzido pelos holandeses na Guiana e nas Antilhas, fazendo com que para manter um preço competitivo no mercado, tinha-se que diminuir os custos de produção, sobretudo nos gastos

1 Doutorando em história social pela Universidade Federal Fluminense, atualmente pesquisa as fronteiras sociais na Capitania de Angola, segunda metade do século XVII, orientado pelo prof. Dr. Alexandre Vieira Ribeiro. Mestre em história pela Universidade Federal de Pernambuco, a qual realizou pesquisa sobre o governo de João Fernandes Vieira em Angola, orientado pelo prof. Dr. José Bento Rosa da Silva. Especialista em história da África pela Fundação de Ensino Superior de Olinda. Graduado em história pela Universidade Federal Rural de Pernambuco. Foi professor de história da África no departamento de história da Fundação de Ensino Superior de Olinda, entre 2012 e 2015. 
com a mão de obra escrava africana, que tinha aumentado consideravelmente com as guerras atlânticas. Para tanto, em 1654, o negocio negreiro em Angola abastecia o comercio carioca, e era de fundamental importância para a produção açucareira em Pernambuco resgatar o comercio bipolar entre Luanda-Recife, como também utilizar ações que proporcionassem um aumento nos números e baixa nos preços no mercado escravista.

Desde 1646 houve uma preocupação em Pernambuco com relação ao que acontecia em Angola, os mestres-de-campo ${ }^{2}$ Martin Soares Moreno, Vidal de Negreiros e João Fernandes Vieira enviaram à Corte relatórios sobre os acontecimentos do Congo e de Angola, informações de luandenses no Recife que tinham vindo como prisioneiros. Nesses relatórios, João Fernandes Vieira alerta a Coroa sobre as manobras de Salvador de Sá, que seu interesse em Angola esteve restrito aos negócios peruleiros da prata, segundo Vieira isso poderia provocar uma investida Espanhola contra Luanda, já que por conta dos conflitos atlânticos houve uma grande crise internacional no mercado de escravos (ALENCASTRO, 2000, p. 259).

Em 1654, o almirante Brito Freyre, que foi governador de Pernambuco de 1661 a 1664, tentou convencer a Coroa lusa do projeto de reconquista de São Jorge da Mina, e propôs o ataque logo depois da rendição holandesa, tendo como o Recife a base da saída da expedição (ALENCASTRO, 2000, p. 270-271). Mesmo a Coroa não aprovar o projeto, ficou evidente a preocupação de Pernambuco com os acontecimentos na África central e a necessidade de estar no controle do negocio negreiro.

Um dos líderes do movimento de libertação, que teve prestígio perante a Coroa pelas ações militares na expulsão dos holandeses, João Fernandes Vieira, arquitetou a resolução desse problema comercial, usou a política de favorecimentos no comercio Recife-Luanda, pois foi um dos maiores senhores de engenho de Pernambuco e Paraíba, e nada melhor para reverter o trato negreiro em seu benefício do que sendo governador de Angola.

Foi muito conveniente que enquanto João Fernandes Vieira governasse Angola, André Vidal de Negreiros $^{3}$ governasse Pernambuco $^{4}$, as duas costas atlânticas com o mesmo objetivo, aumentar a produção açucareira através de uma bem sucedida forma de governar Angola baseado

2 Mestre-de-campo é equivalente a coronel de infantaria, tem a jurisdição civil e criminal do seu terço com apelação ao general (BLUTEAU, 1712, p. 457).

3 Negreiros também era um dos grandes senhores de engenho da América portuguesa, como Vieira, usou seu prestígio para ser governador de Angola, de 1661 a 1666, e também teve o interesse voltado no tráfico de escravos e produção açucareira.

4 Inicialmente seu mandato seria de 1657 a 1660, mas em 1660, Negreiros requer a Coroa que lhe mantenha no cargo até o fim do mandado do governador de Angola, João Fernandes Vieira, em 1661. (AHU-ACL-CU-015, Cx. 7, D. 620). 
no trato negreiro. É justamente esse o objetivo desse artigo, através da historiografia clássica, dos manuscritos do Arquivo Histórico Ultramarino, dos documentos publicados na Monumenta Missionária Africana e dos relatos dos cronistas, analisar as ações de João Fernandes Vieira na Capitania de Angola, levando em consideração seus interesses Atlânticos.

\section{Primeiras medidas para o governo em Angola}

Desde que o Rei de Portugal, D. João IV, lhe concedeu o governo de Angola em carta patente datada de 8 de julho de 1654, a principal preocupação de Vieira foi o fortalecimento militar, pois como ainda se encontravam na ativa as guerras luso-holandesa e luso-espanhola, os riscos de novas invasões nos territórios do Brasil e de Angola foram altos, além da insegurança marítima, onde era possível a pirataria, sobretudo de navios ingleses e holandeses ${ }^{5}$. Vieira governou a Paraíba planejando seu governo em Angola, e logo fez solicitações a Coroa portuguesa a respeito de reforçar as defesas angolanas, principalmente com militares que tinham acumulado experiências nas lutas contras os holandeses no Brasil. Uma consulta do Conselho Ultramarino a Rainha regente D. Luísa de Gusmão, datada em 22 de novembro de 1656, dois anos antes de Vieira assumir o governo angolano, nos mostra que Vieira solicitou a licença para transferir duzentos soldados da Capitania de Pernambuco para Angola ${ }^{6}$. Além de soldados, Vieira solicitou armamentos, munições e gente preparada para servir ao arsenal militar, como nos mostra Mello:

Pediu também permissão para conduzir de Pernambuco 3 mil mosquetes e arcabuzes com os seus aviamentos, por lhe constar haver lá falta deles e para que do Reino se lhe enviassem 100 quintais de pólvora com a munição necessária e dois oficiais de serralheiros ou armeiros para concerto das armas [...] Solicitou ainda autorização para levar de Pernambuco 6 peças de artilharia, por lhe parecer, à vista da planta da cidade de Luanda, que seria necessário fazer-se de novo uma fortaleza na ponta da ilha do mesmo nome ou reedificar-se o Forte do Penedo e guarnecê-lo com artilharia que não havia ali [...] Pediu ainda que se mandasse conduzir a Angola 400 infantes, por haver ali grande falta de infantaria, que era a principal força que consistia sua defesa, por não haver outra nem por mar nem por terra [...] (2000, p. 331-332).

5 Um dos documentos que comprovam essa afirmação foi a Consulta do Conselho Ultramarino ao Rei D. João IV, de 12 de setembro de 1654, onde se tem informações de que holandeses e ingleses estavam armando esquadras contra o Brasil e Angola. (AHU-ACL-CU-015, Cx. 6, D. 497).

6 Baseado no AHU, Angola, caixa 6, $\mathrm{n}^{\circ}$ 83, 84, 86, 141, Luis Felipe de Alencastro afirma que Vieira solicitou 400 soldados, o que aumentou ainda mais as pretensões de Vieira. (ALENCASTRO, 2000, p. 274-275). Já a informação que trás o número da solicitação de 200 soldados está em AHU-ACL-CU-015, Cx. 7, D. 576. 
Em consulta do Conselho Ultramarino datada de 23 de novembro de 1656, Vieira com a justificativa de que precisava de força militar para conquistar os sertões de Angola, também solicitou um número de cavalos que podiam formar duas companhias, o mesmo ofereceu seus cavalos, mas solicitou oficiais para as companhias (MELLO, 2000, p. 332-333). Os cavalos foram de fundamental importância nas guerras angolanas, levados para Angola de regiões como Cabo Verde, Espanha, Argentina, Itália e Brasil, no tráfico de escravos os navios que levassem cavalos para Angola tiveram a preferência na liberação do porto. Os cavalos usados na guerra foram um terror para os povos bantos, pois os mesmos achavam que os animais eram demônios, e isso afetou parte do psicológico dos soldados nas batalhas, vinte cavaleiros na frente de batalha causavam um temor maior do que uma infantaria inteira. O cavalo também possibilitou mobilidade às forças governamentais: comunicação, patrulhamento e reconhecimento (FERREIRA, 2007, p. 10).

A Coroa portuguesa foi aconselhada de que partes das solicitações de Vieira foram desnecessárias, quem deu o parecer sobre a solicitação "exagerada" de Vieira foi Salvador Correia de Sá em consulta ao conselho ultramarino datada em 23 de novembro de 1656 (BRÁSIO, 1981, p 83), essa atitude de Salvador de Sá poderia estar ligada a disputa pelo comercio de escravizados, entre Recife e Rio de Janeiro, ou então pelo fato de Salvador de Sá não se achar responsável por ter deixado Angola desprotegida enquanto foi governador. A Coroa entrou em acordo com o parecer de Salvador de Sá, tanto que da Capitania de Pernambuco, dos duzentos soldados solicitados só foram liberados $\mathrm{cem}^{7}$, dos três mil mosquetes apenas mil armas sortidas, dos cem quintais de pólvora o Reino mandaria o possível, dos oficiais serralheiros ou armeiros apenas os degredados, das seis peças de artilharia apenas quatro que não fossem de bronze, dos quatrocentos infantes apenas alguma infantaria, as demais solicitações foram atendidas (MELLO, 2000, p. 331-333).

Para realizar seus interesses, Vieira teve que criar uma rede de influências com pessoas de confiança na sua administração, por isso ele conseguiu uma transferência de gente sua de Pernambuco para Angola, em diversas áreas, como no corpo militar, administrativo e religioso, ocupando os cargos de confiança no governo angolano. O interesse de Vieira era de expandir o território português no interior da África central, recuperar as alianças e submeter à maior ameaça para a Coroa, o Reino do Congo, além de tentar eliminar os intermediários no trato negreiro, pois na sua perspectiva não se negociava com nativos e sim os conquistava. Para tanto, os militares de Pernambuco foram muito úteis, pois já tinham experiências em batalhas no ultramar.

7 De acordo com o relato do cronista Cadornega, Vieira desembarca em Angola com 200 soldados vindos do Brasil (1940, p. 139). 
Além dos soldados vindos de Pernambuco, Vieira levou gente para os postos de comando, Francisco Ferreira de Vasconcelos e Antônio Jorge de Góes, veteranos das duas batalhas dos Guararapes, ocuparam o cargo de Sargento-mor, homens com grande experiência em combate, o próprio Antônio Góes ocupou o cargo de Capitão-mor de Benguela, de 1661 a 1664. Para capitão de infantaria, ocupam Francisco César ou Agostinho César de Andrade, seu cunhado e protegido ${ }^{8}$, Manoel Berenguer de Andrade ${ }^{9}$, sobrinho ${ }^{10}$ da sua esposa e filho de seu procurador em Lisboa Gaspar Berenguer de Andrade, e Sebastião Muniz da Câmara também seu parente. Vieira também levou para o seu lado Capitães expedicionários de 1648 que ainda estavam em Angola, como o caso de Álvaro de Aguilar Osório e Francisco Vaz Aranha, e como secretário de governo Vieira nomeou Antônio de Buíça, que já tinha ocupado esse posto antes e tinha boas relações com os militares veteranos. Vieira também levou o antigo capelão-mor do seu terço ${ }^{11}$ de infantaria em Pernambuco, o beneditino Frei João da Ressurreição, chamado de Frei Poeira, que ocupou o cargo de capelão-mor da tropa em Luanda. Houve protesto dos moradores de Angola contra a ocupação dos cargos por gente vinda do Brasil, a justificativa de Vieira foi de que seus homens estavam adaptados as guerras tropicais e seriam de grande importância para a expansão e combate com os sobas ${ }^{12}$ inimigos (MELLO, 2000, p. 333).

O desembarque e a posse de Vieira em Angola no dia 18 de abril de 1658 foi muito festejada pelos moradores, Vieira chegou com muito prestígio pela expulsão holandesa em Pernambuco, e o mesmo fez questão de expor seus títulos como Cavaleiro da Ordem de Cristo, Membro do Conselho de Guerra, comendas de São Pedro de Torrados, e de Santa Eugênia da Ala, e Alcayde-mor da vila de Pinhel, e, sobretudo primeiro aclamador da liberdade divina no Brasil (CADORNEGA, 1940, p. 140). Vieira foi visitado por vários embaixadores de sobas africanos, com seus presentes. Recebeu a visita do embaixador da Rainha Nzinga de Matamba, agora aliada dos lusos, pela conversão definitiva ao cristianismo em 1656. E recebeu também a visita do embaixador do Reino do Congo, a qual sua autoridade foi posta em prova pelo fato de que o embaixador ao anunciar quem estava a representar, o Rei do Congo, e que tinha como um dos títulos" "rei de

8 Cadornega informa que seu cunhado se chama Francisco César (1940, p. 139), mas Luis Felipe de Alencastro (2000, p. 275-276) e José Antonio Gonsalves de Mello (2000, p. 333) informam a nomenclatura de Agostinho César de Andrade como seu cunhado.

9 Será assassinado em Luanda pelo Capitão Álvaro de Aguilar Osório, segundo Elias Correia, o crime acontece pelo motivo de que Berenguer invade a casa de Álvaro Osório (CORRÊA, 1937, p. 277).

10 José Antonio Gonsalves de Mello afirma que Manoel Berenguer foi primo da esposa de Vieira (2000, p. 333).

11 Um Terço, enquanto "termo militar", responde ao que os romanos chamavam Legião e os alemães e franceses chamam Regimento, ou seja, era um agrupamento de infantaria (BLUTEAU, 1712, p. 110).

12 Chefes locais na África central.

13 Mani Congo por graça de Deus Rei do Congo, de Angola, Macambá, Ocanga, Cumba, Lula, Zuza, senhor do ducado de Buta, Suda, Bamba, de Ambuíla e suas províncias, senhor do condado do Sonho, Angola e Caconge e da monarquia dos Ambondaras e do grande e maravilhoso Rio Zaire (MELLO, 2000, p. 334). 
Angola". Vieira ordenou que o embaixador riscasse o título e alertou que o senhor do Congo não deveria utilizar esse título, o embaixador obedeceu Vieira e quando retornou a São Salvador, capital do Congo, o Rei Garcia II, não se conformou com o acontecido e mandou degolar o embaixador que obedeceu a Vieira (MELLO, 2000, p. 334-335).

Nas suas primeiras medidas Vieira procurou se estruturar militarmente, mandou que ocupassem os cargos de milícias vagos e das fortalezas, nomeando gente de sua influência. Completou as obras da fortaleza de Santo Amaro com um custo baixo, reedificou a fortaleza de Benguela que estava quase destruída, ampliou o forte de Penedo, e construiu o cais do desembarcadouro em Luanda, que foi de grande utilidade para o comercio (BRÁSIO, 1981, p. 239). Essas ações de Vieira proporcionou uma melhor defesa da costa de Angola, que ao longo do seu governo combateu várias embarcações de piratas holandeses e ingleses que saqueavam e negociavam com sobas inimigos de Portugal, contrabandeando escravos e outros produtos (CADORNEGA, 1940, p. 163, 173-174). Em 1658 Vieira capturou e levou para Luanda um navio inglês que contrabandeou escravos e marfim na costa da África central. Em 1660 dois corsários holandeses foram combatidos, um deles foi capturado. Em 1661 um navio vindo de Lisboa foi atacado por uma nau holandesa próximo do porto de Luanda, o socorro foi imediato e os holandeses fugiram sem saquear a embarcação, no mesmo ano outro navio holandês foi capturado no norte de Angola acusado de pirataria (CORRÊA, 1937, p. 276).

Essa movimentação de outras nações europeias na costa de Angola fez com que Vieira tivesse a justificativa para solicitar mais homens e munições para a defesa angolana, reforços que foi utilizado por ele nas guerras no sertão. Em carta de Vieira para a rainha mãe regente D. Luisa de Gusmão, solicitou pólvora para a defesa da praça, mais 300 homens para suprir os falecidos, a qual relatou sobre os navios inimigos, justificando a solicitação (BRÁSIO, 1981, p.237,239).

\section{Os conflitos militares na África Central}

No século XVII as tropas regulares portuguesas na África Central tinham em torno de mil soldados. Luanda e Benguela foram os centros da administração e do corpo militar, com algumas fortalezas no interior como Muxima, Ambaca, Massangano, Cambambi, Mpungu e Ndongo. Em tempo de guerra o grosso do exército era de soldados locais, através de alianças com os sobas. Os europeus que faziam parte do exercito eram na maioria degredados, de crimes civis ou religiosos, e 
ainda assim sofriam na adaptação, nas questões climáticas e epidemiológicas, a qual muitos padeceram sem mesmo ter ido ao combate. Por estas questões, todo navio vindo de Pernambuco trazia em média dez recrutas para as guerras angolanas. Ao tempo, Vieira resgatou várias alianças e territórios, e apesar do grosso do exército ter sido de africanos, muitos soldados do Brasil foram para Angola, como o terço dos Henriques (FERREIRA, 2007, p. 4-8). Os conflitos entre os grupos africanos, e o uso deles como soldados para lutar pelos portugueses, se enquadra nos vários interesses entre os grupos locais, cada grupo pretendeu tirar vantagem da situação da melhor forma possível.

Vieira saiu de Pernambuco em direção a Angola com a decisão de fazer guerra ao rei do Congo por conta da dificuldade que o mesmo provocou no trato negreiro português. Os Problemas de Portugal e o Reino do Congo foram de longa data, mas a situação se agravou em 1641, quando Garcia II, Kimpaco, destronou seu irmão e assumiu a coroa do Congo, no mesmo ano que o holandeses chegaram em Luanda, Garcia II prestou auxilio aos flamengos com tropas negras, para combater os lusos, que se refugiaram em Massangano. Esse mesmo rei, em maio de 1643, enviou embaixadores seus para negociar o trato negreiro diretamente com Mauricio de Nassau, no Recife. Durante toda a ocupação holandesa em Angola, Garcia II com Nzinga, influenciaram a África central a se levantar contra os portugueses, além do que, o Congo recuperou terras que os portugueses tinham ocupado com a colonização em Angola, absorvendo grande número de escravos. Outro problema foi que Garcia II admitiu em suas terras, frades capuchinhos italianos e espanhóis. A política externa do reino do Congo foi de romper com os intermediários nas questões econômicas, políticas, e religiosas, diminuindo ainda mais as influências portuguesas na região (ALENCASTRO, 2000, p. 284-285).

Com a reconquista de Angola em 1648, Salvador de Sá enviou tropas sob o comando de Bartolomeu de Vasconcelos da Cunha, em direção ao Congo, degolando os sobas inimigos no caminho, com essa ameaça, Garcia II enviou embaixadores para um tratado de paz em Luanda, e que nas obrigações estavam devolver terras anexadas no período dos holandeses e restituir todos os escravos fugidos e capturados. Este tratado não foi cumprido e Garcia II enganou os governadores anteriores a Vieira com a promessa de fazer cumprir o tratado. A grande questão foi que Garcia II não esteve isolado, teve aliados no clero mestiço do Congo que negociou assuntos diretamente com Roma e ainda com Madri ${ }^{14}$, além dos outros Estados marítimos europeus, com quem teve negócios

14 Em 6 de outubro de 1660, o secretário da Propaganda Fide enviou uma carta ao Cardeal Vírginio Orsini, solicitando que se peça ao governador de Angola que compreenda mais o rei do Congo (BRÁSIO, 1981, p. 309). 
através do porto de Pinda. Essas questões fizeram com que uma guerra direta contra ele devia ter uma boa justificativa repassada pelos portugueses (ALENCASTRO, 2000, p. 286).

Desde que chegou em Angola, Vieira tratou de justificar a guerra contra o Congo, tentou criar uma rede de influências para ter uma base aliada que lhe deu mais credibilidade perante a Coroa. Nas cartas enviadas a Coroa portuguesa, Vieira fez questão de mostrar que sempre consultou o conselho de Luanda nas decisões, e que sempre teve unanimidade nos votos. Talvez foi um interesse em comum a guerra contra o Congo, pois no governo de Luís Martins de Sousa Chichorro a câmara de Luanda teve a mesma atitude de apoiar a guerra ${ }^{15}$, Alencastro discorda e tem a ideia de que:

Manipulada por João Fernandes, a Câmara de Luanda se aparta de sua política tradicional, favorável ao trato indireto mediante o comércio sertanejo, e apoia a guerra do Congo. Num documento cuja fanfarronice mostra que seus autores molharam a pena no tinteiro de João Fernandes (2000, p. 285).

O documento que Alencastro se referiu foi a carta da câmara de Luanda ao Rei D. Afonso VI, datada de 29 de abril de 1659 (BRÁSIO, 1981, p. 231-233), a qual a câmara justificou a guerra pelo fato de que muitos moradores estavam empobrecidos por conta da dificuldade de comercializar escravos, pois muitos fugiram e foram acobertados nas terras do Congo, houve um sentimento de insegurança na posse dos escravos, os mesmos reclamaram da administração de Salvador Correia de Sá, que havia fugido da guerra contra o Congo e Quissama, e que Vieira era a pessoa certa para fazer guerra ao Congo, pelo seu prestígio militar e temor que já tinha conquistado na África central, e por conta do não cumprimento do acordo com Salvador de Sá, a câmara de Luanda tinha proposto a guerra ao Congo desde 1655, e que esse conflito não podia passar do triênio de Vieira como governador. $\mathrm{O}$ conteúdo do documento ainda revela que houve agentes do tráfico negreiro mal intencionados em Luanda, sugerindo que a Coroa tivesse o cuidado de só fazer contratos com gente de confiança do governo de Angola. Apesar do interesse em comum, ficou evidente o alinhamento da câmara com os objetivos de Vieira, a troca de favores na sua rede de influências foi desde reclamações com o seu desafeto, Salvador de Sá, como também indicou pessoas de Vieira para o trato negreiro.

15 Auto sobre a declaração de guerra a D. Garcia II, Rei do Congo, datada de 9 de junho de 1657 (BRÁSIO, 1981, p. 124-125). 
A carta da câmara de Luanda retratou parte das justificativas que Vieira colocou em outras correspondências ao Rei, na declaração de Vieira ao conselho e junta de guerra datada de 9 de setembro de 1658 (BRÁSIO, 1981, p. 172-175), ele enfatizou que os portugueses estavam sem reputação de armas, pelas várias derrotas no período de ocupação holandesa, ele deu um exemplo da carta de um oficial de guerra no sertão que disse que vários sobas só obedeciam ao rei do Congo e a rainha Nzinga de Matamba, e que alguns sobas aliados lusos foram vítimas dos aliados do Congo, como o jaga Calandula, que foi degolado por se manter fiel aos lusos, e também o soba D. Simão, do Dembo, que ameaçou romper a aliança se Portugal não oferecesse a proteção necessária aos seus vassalos. O soba Cassange também ameaçou romper com o tratado comercial com os lusos por conta do perigo nas rotas do Libolo, Quissama e Congo. Vieira relatou que tudo isso foi um desaforo e um desrespeito, logo a Coroa devia dar a autorização para ele combater os sobas rebeldes e reconquistar a reputação de armas, recuperando as rotas comerciais terrestres e até mesmo as missões de evangelização nas regiões. A junta de guerra deu parecer favorável a Vieira, e sobre o reino do Congo a ordem foi cobrar o cumprimento do acordo feito no período de Salvador de Sá.

Depois de ter consultado a câmara de Luanda e de ter tido o apoio necessário, Vieira criou um documento de declaração de guerra ao Reino do Congo, datado de 11 de março de 1659 (BRÁSIO, 1981, p. 224-229) ${ }^{16}$, com várias justificativas para o conflito, Vieira iniciou culpando o Congo e Garcia II como principais responsáveis pela perda de Angola aos holandeses. Lembrou ainda sobre o envio de embaixadores do Congo para o Recife negociar com Mauricio de Nassau. Acusou Garcia II de ter cometido várias atrocidades contra os lusos, mais do que todos os inimigos juntos, como saques a fazendas, vilas e vassalos da Coroa portuguesa. Levantou a questão que o catolicismo praticado no Reino do Congo era superficial, o mesmo tinha suas práticas pagãs e o próprio rei não utilizava seu nome cristão ${ }^{17}$. Vieira ainda teve a informação de que Garcia II tinha entrado em contato com Nzinga recentemente para uma possível aliança contra os lusos ${ }^{18}$. Vieira acusou também Garcia II de enganador, pois não tinha cumprido o acordo que tinha feito com Salvador de Sá, trapaceou com falsas promessas os outros governadores, e quis fazer o mesmo com Vieira. No documento Vieira relatou que no inicio do seu governo tinha dado um ultimato ao Rei do Congo, o mesmo tinha oito meses para cumprir o acordo de Salvador de Sá, senão haveria a guerra.

16 Em 20 de dezembro de 1661, André Vidal de Negreiros utiliza esse documento para aumentar seus argumentos na guerra com o Congo.

17 Informações que Vieira adquiriu através de padres capuchinhos que tinham vindo de São Salvador, capital do Congo. Essa foi uma das principais justificativas de André Vidal de Negreiros para a guerra. Esse caráter pagão do cristianismo do reino do Congo foi um assunto que preocupou Roma, o Papa Alexandre VII, enviou uma carta a Garcia II, datada de 5 de outubro de 1660, que incitou o rei de exterminar as práticas pagãs viciosas da população (BRÁSIO, 1981, p. 301-302).

18 Desde 1656 Nzinga tinha sido neutralizada como ameaça aos portugueses por conta da sua conversão ao cristianismo e o acordo diplomático com o governador Luis de Sousa. 
Próximo do prazo chegar ao fim, o rei do Congo enviou, talvez para ganhar tempo ou até mesmo enganar, 200 escravos formados de velhos e crianças, o que para Vieira foi um grande desaforo. $\mathrm{Na}$ perspectiva de Vieira o Congo funcionou como um grande quilombo, como acontecia em Pernambuco com o Quilombo dos Palmares, a qual escravos fugidos tinham proteção. Três dias depois da declaração, Vieira teve o apoio unânime dos conselheiros de Luanda, e os mesmos afirmaram que o exército e os aliados estavam prontos para a guerra.

Sem a autorização para a guerra, Vieira escreveu ao Rei D. Afonso VI, em 7 de maio de 1659 (BRÁSIO, 1981, p. 234-236), solicitando a autorização com novas justificativas, Vieira relatou que não tinha como negociar uma paz, pois já tinha oferecido amizade ao rei do Congo em troca do cumprimento do acordo de Salvador de Sá, e que Garcia II continuava acobertando escravos fugidos em suas terras, e que a única alternativa para recuperar o prestigio era fazer guerra ao Congo, o mesmo enfatizou que se o Congo for derrotado os sobas rebeldes também seriam, e que o melhor mês para a guerra seria no próximo mês de junho ${ }^{19}$. Nessa carta Vieira teve o apoio de uma junta religiosa, formada por franciscanos, capuchinhos e jesuítas, apoiando a guerra e relatando o caráter pagão do cristianismo no Congo.

Três dias depois Vieira enviou outra carta ao Rei de Portugal (BRÁSIO, 1981, p. 237-239), enfatizando seus feitos como governador e capitão-general, relatou sobre a captura de embarcações holandesas e inglesas na Costa de Angola, como também o sucesso na guerra dos sertões com os sobas rebeldes de Ambaca, Libolo, Benguela e Quissama. Relatou também sobre suas obras de fortificação de Luanda com custos baixos para a Coroa. Uma forma de justificar ainda mais a guerra contra o Congo, mostrando a sua competência como gestor e militar passando mais credibilidade para a Coroa. Quatro meses depois, Vieira escreveu outra carta ao Rei D. Afonso VI, datada de 24 de setembro de 1659 (BRÁSIO, 1981, p. 271), a qual relatou a vontade do povo de Luanda em fazer guerra ao reino do Congo, desde o tempo de Luis de Sousa Chichorro, e que continuam aguardando a autorização da Coroa.

Na documentação ficou evidente a determinação de Vieira em combater o reino do Congo, o que só aconteceu em 1665 com o seu sucessor André Vidal de Negreiros, o receio da Coroa portuguesa em atender as reivindicações de guerra estava relacionado com o contexto europeu, pois Portugal ainda estava em conflito com a Espanha e a Holanda, e uma guerra aberta ao Congo poderia ter tido um custo muito alto, além da possibilidade da derrota e colocar em risco os

19 Talvez pelo fato das chuvas favorecerem as tropas vindas do Brasil. 
territórios já conquistados. Mas a insistência de Vieira diminuiu pelo fato de que, ou no fim de 1659 ou no inicio de 1660, o rei do Congo cumpriu parte do acordo de Salvador de Sá, entregando parte dos escravos fugidos que estavam em suas terras, Vieira mandou entregar os escravos aos seus devidos donos (CADORNEGA, 1940, p. 181). Vieira não conseguiu a guerra contra o Congo, mas parte do acordo cumprido por Garcia II foi algo que nenhum dos seus antecessores conquistou, as campanhas aos sobas rebeldes impactaram os congoleses.

Com a autorização de combater os sobas rebeldes na junta de 9 de setembro de 1658, e enquanto esperava a posição do Congo com relação ao ultimato, Vieira organizou um exército de 400 homens, entre soldados pagos, moradores e sertanejos, para combater nos sertões. Sob o comando do capitão-mor Bartolomeu de Vasconcelos da Cunha, marcharam para Ambaca, terra do soba Angolomem Acayta, que foi aliado de Nzinga no período dos holandeses, e que matou muitos portugueses nas campanhas militares dos Empures $^{20}$. No caminho recrutaram mais homens em Massangano, e alguns quimbares ${ }^{21}$ aliados de D. Felipe do Ndongo e do jaga Cabucu Candongo. O conflito foi em campo aberto, e foi uma grande vitória das tropas de Bartolomeu da Cunha, e muitos derrotados se refugiaram nas cavernas. Bartolomeu criou um cerco que durou quatro meses (CORREAA, 1937, p. 275), em que morreram muita gente de fome, tanto nas cavernas como entre os soldados aliados lusos, a rendição dos rebeldes aconteceu e os seus líderes foram degolados, e os prisioneiros feitos de escravos, repartidos ${ }^{22}$ entre os oficiais e soldados lusos, os moradores de Massangano ficaram de fora da partilha, o que gerou muita insatisfação (CADORNEGA, 1940, p. 141-142).

Com a vitória em Ambaca, as tropas seguiram para combater os sobas Dambi Angonga e Quitexi Cambamb nas matas fechadas da terra dos Dembos, que na perspectiva dos portugueses, haviam cometidos insultos contra os vassalos da Coroa portuguesa, além da resistência ao cristianismo e a ocupação lusa na região. Na empreitada houve a substituição de comando, Bartolomeu da Cunha foi substituído por João de Oliveira Delgado, vindo do Reino de Portugal, o que foi um erro pelo fato do conflito ter exigido uma liderança com experiência em combate com a geografia local, sobretudo as táticas de guerrilha vindas do Brasil. No conflito houve muitas baixas dos dois lados, muitos dembos fugiram para as terras do Congo, João Delgado sofreu várias derrotas, e foi acusado de tratamento desumano com os seus soldados, muitos passaram fome e não foram pagos, o que fez com que muitos soldados de Massangano desertassem levando parte das

20 Negros que tinham se refugiado em cavernas próximo de Ambaca.

21 Capitães dos agrupamentos negros.

$221 / 5$ era destinado a Coroa. 
munições. Esses acontecimentos levaram ao fracasso da campanha, fazendo as tropas retornarem para Ambaca, e o capitão-mor João Delgado foi preso e mandado de volta a Portugal por Vieira (CADORNEGA, 1940, p. 150-155) ${ }^{23}$.

Os sobas da região de Libolo tinham se rebelado contra os vassalos lusos, impediam a passagem do comércio de marfim. Vieira consultou o conselho e teve a aprovação da guerra na região, conseguiu 130 homens de Angola, somados aos soldados negros comandados por Carirei de São Tomé. Atravessaram o rio Cuanza, lutaram e venceram, criaram novas rotas comerciais e novos aliados, principalmente por conta das missões dos capuchinhos. O soba Gumza Ambambe da província do Aco, se tornou um grande aliado, avassalando outros sobas da região, como o Quilembe Lembi da província dos Sumbis, próximo aos rios Nica e Cubo (CADORNEGA, 1940, p. 157-162).

Na região de Benguela, apesar de ter sido recuperada no período do governo de Salvador de Sá, havia saqueadores do soba Caconda que estavam atrapalhando o comercio terrestre. Vieira nomeou Manoel de Tovar Fróis como capitão-mor de Benguela, o mesmo restaurou uma certa paz na região através de negociações e de conflitos armados, criando um percurso terrestre seguro entre Benguela e Luanda, além de recuperar o trato das salinas no sul (CUNHA MATOS, 1963, p. 280).

Essas conquistas militares geraram um novo ciclo de vassalagem entre os sobas e a Coroa portuguesa representada em Angola pelo governador geral, além de recuperar a reputação de armas que os lusos tinham perdido com o período holandês, o que serviu para pressionar ainda mais o reino do Congo em cumprir o acordo feito com Salvador de Sá. Mesmo com esse aspecto positivo para Portugal nas ações de Vieira, o mesmo foi acusado de ter criado guerras no sertão apenas para gerar escravos e transporta-los para Pernambuco. Alguns moradores de Angola através do provedor escreveram ao rei, em 1660, acusando os governadores nesse jogo de interesses ${ }^{24}$, como explica Alencastro:

O provedor de Angola expusera de maneira arrasadora a pilhagem brasílica em Angola. Segundo ele, os governadores atacavam os sobas aliados, escravizando nativos e mandando-os para o Brasil. João Fernandes cativava um sobado inteiro da região do Libolo, despachando esses vassalos de S.M. para o Brasil, onde toda essa gente está em um

23 José Antonio Gonsalves de Mello (2000, p. 342) afirmou que Vieira acusou João Delgado de traição, e que o mesmo queria dar um golpe, assumindo o posto de governador, e ainda amotinando alguns moradores e soldados da povoação de Massangano. Ver também carta de Vieira ao Rei de Portugal, datada de 6 de outubro de 1660 (BRÁSIO, 1981, p. 305-306).

24 Em carta de 22 de outubro de 1660, o rei proibiu o uso de moradores de Angola nas guerras dos sertões, salvo os casos de ações defensivas (Arquivos de Angola, 1936, p. 133-134). 
engenho do dito João Fernandes Vieira (2000, p. 289).

Vieira usou a sua rede de influências estabelecida em Angola para se defender dessas acusações. O mesmo em outras situações preferiu não fazer guerra, ou pelo menos não foi autorizado, para resolver dois problemas entre sobas do sertão. O primeiro foi na região de Quissama, o soba Mulumba Acambolo procurou Vieira para pedir proteção e a construção de uma fortaleza para marcar território contra seu inimigo, o soba Cafuxi. Vieira consultou a câmara de Massangano que informou que já existia uma fortaleza na região próxima de Muxima. Vieira mandou um embaixador para Quissama, a qual negociou a paz entre os sobas, estabelecendo boas relações comerciais, sobretudo recuperando o trato salino no rio Cuanza (CADORNEGA, 1940, p. 165-166). A outra situação foi que o rei do Ndongo, D. Felipe, invadiu e saqueou terras da província do Aco, o soba Amgolomen Acacombe solicitou intervenção de Vieira, e o mesmo ordenou que D. Felipe devolvesse as terras e os produtos dos saques, D. Felipe como um bom vassalo obedeceu ao governador (CADORNEGA, 1940, p. 175-176).

Com relação a rainha Nzinga, que se aliou aos lusos no governo de Chichorro, tem o relato que em 1658, Nzinga combateu uma invasão do rei de Quissica em suas terras, conquistando uma grande vitória, a partir daí ela se dedicou ao cristianismo até a sua morte em 1663 (CUNHA MATOS, 1963, p. 281). Em julho de 1660, chegou em Angola, vindo do reino de Matamba, o frei capuchinho Antonio Romano, ele levou de Massangano gente e material para construir uma grande igreja em Matamba, tudo pago pela rainha Nzinga através de escravos (CADORNEGA, 1940, p. 167, 172). Nesse momento surgiu noticias de que escravos estavam fugindo da Angola para Matamba, em carta de 15 de junho de 1660 (BRÁSIO, 1981, p. 289), enviada a Cadornega, Nzinga se isentou da culpa e se colocou a disposição na ajuda de recuperar os negros fugidos. 


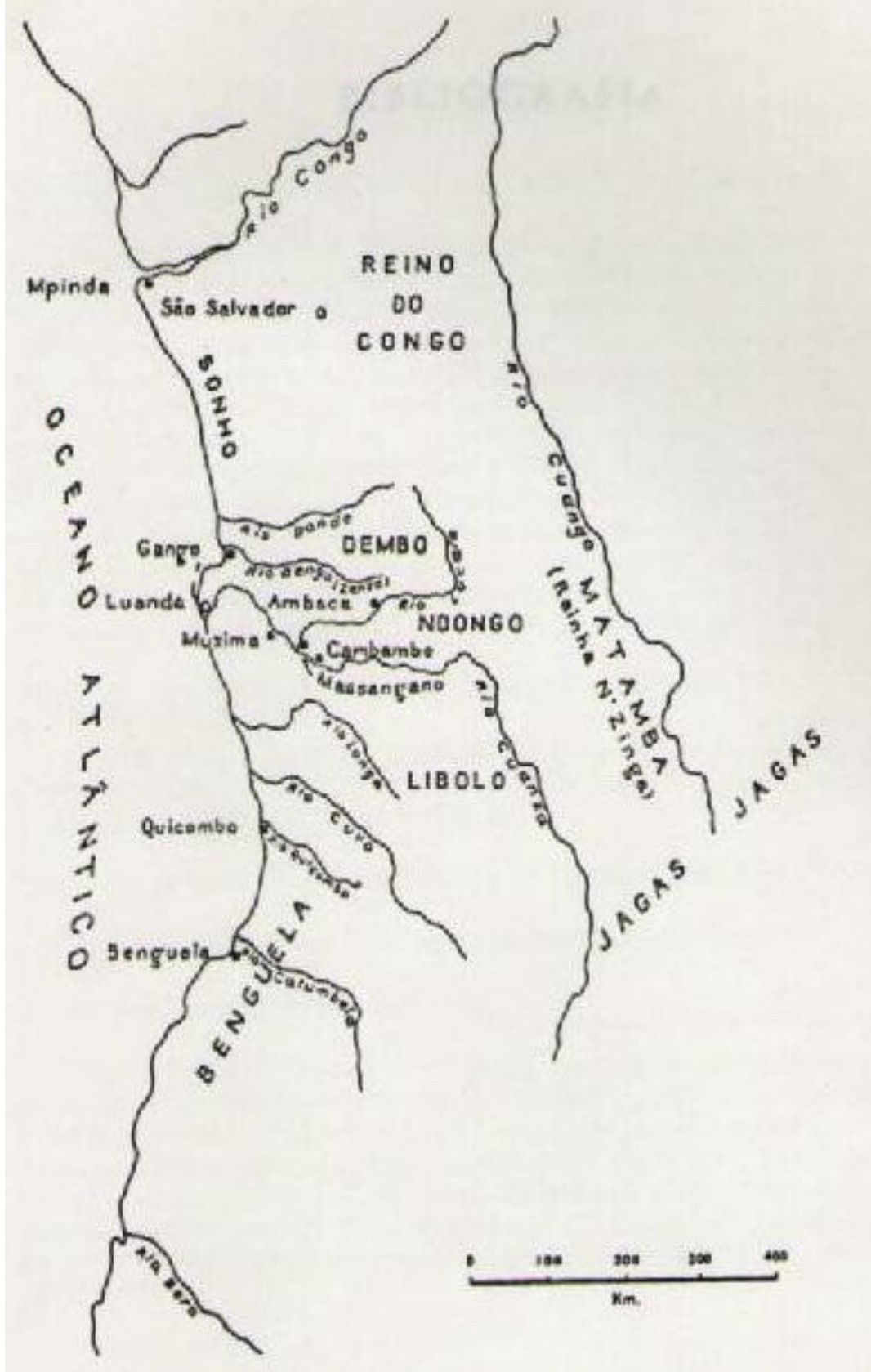

O reino de angola em 1658-1661 (MELLO, 2000, p. 449).

\section{Os conflitos com Massangano}

Vieira tinha colocado gente sua vinda do Brasil para ocupar cargos de maior importância no governo de Angola, e tinha que conseguir o apoio da gente da terra na sua rede de influências, ele teve que tentar compensar essa diferença de tratamento entre os chegados e os colonos da terra, principalmente com os moradores de Massangano, que tinha sido o lugar de resistência lusa aos sete 
anos de conflitos no período holandês. Portanto Vieira solicitou e teve a autorização para transformar a fortaleza de Massangano a categoria de vila, com uma câmara própria. Em carta datada de 18 de julho de 1658 (BRÁSIO, 1981, p. 169), Vieira enalteceu a importância da região e dos seus moradores, e da necessidade de fazer a câmara. Para ocupar os cargos de Juiz, vereadores, procurador do conselho e tesoureiro, Vieira solicitou que fossem homens nobres, casados e que fossem moradores da vila. Em carta de 20 de setembro de 1658 (BRÁSIO, 1981, p. 170) a vila mandou uma carta ao governador confirmando a nomeação dos vereadores, e ainda mandaram dois deles para Luanda organizar o exércido que foi para as guerras nos sertões. E em outra carta de Vieira para a câmara de Massangano, datada de 8 de novembro de 1658 (BRÁSIO, 1981, p. 171), o governador solicitou a ajuda da vila de Massangano ao exército que marcha em direção a Ambaca.

Essa possível relação amistosa foi abalada, na partilha dos escravos conquistados na luta em Ambaca com o soba Angolomem Acayta, os moradores de Massangano não foram agraciados, o que levou a uma insatisfação geral entre eles. Essa insatisfação foi utilizada pelo novo capitão-mor do reino, João Delgado, para criar um motim. Muitos moradores de Massangano fugiram, levando consigo grande parte da artilharia, o que levou ao fracasso da expedição na região dos Dembos. Em carta de Vieira ao rei D. Afonso VI, datada de 24 de setembro de 1659 (BRÁSIO, 1981, p. 272), o mesmo explicou a situação dos soldados de Massangano que deserdaram com a munição, acusandoos de faltar com as obrigações de vassalos da Coroa. No documento Vieira ainda citou os nomes dos principais líderes do movimento, o capitão Marques e os soldados Lopo do Carvalhal Fogaça, Antonio Ferreira Alfaya, e Antonio Soveral da Fonseca, acusando-os de infiéis a Coroa e exigiu punições aos traidores. No mesmo documento Vieira afirmou que os moradores de Massangano de forma geral não estavam dispostos a obedecer ao governador, principalmente em combater os sobas inimigos. Vieira relatou que teria que impor a obediência, até mesmo porque a câmara de Massangano obtinha as provisões reais.

A situação ficou ainda mais complicada quando os moradores de Massangano criaram uma Casa de Misericórdia sem autorização da Coroa e nem do governador. Em carta de 9 de março de 1661 (BRÁSIO, 1981, p. 320-321), Vieira explicou que houve grande reclamação da Casa de Misericórdia de Luanda, pois as Misericórdias eram sustentadas por esmolas, e com a criação de outra Casa, as esmolas teriam que ser divididas. Vieira relatou ao Rei que não havia necessidade da criação da Casa de Misericórdia de Massangano, pois a vila só possuía 40 soldados, e se fosse necessários eles poderiam ir a Casa de Luanda. Vieira sugeriu na carta que a Casa de Massangano 
fosse destruída, ficando apenas a fortaleza. Vieira ainda acusou os moradores da região de homens de pouca consideração, que não conheciam a lei de Deus e nem temiam pela lei do Rei de Portugal. Outra carta ao Rei, desta vez da própria Casa de Misericórdia de Luanda (BRÁSIO, 1981, p. 323), um dia depois da carta de Vieira, o padre André Pimenta Raposo relatou a dificuldade que vivia a Misericórdia de Luanda, com poucos recursos para acudir tantos enfermos de infantaria, e que a dificuldade seria maior se dividisse as esmolas com a Misericórdia de Massangano. Na carta o padre ainda confirmou a desobediência dos moradores da região.

\section{Vieira e as Ordens Religiosas}

Em 1622, o Papa Gregório XV, criou a Propaganda Fide, um orgão que defendeu uma política missionária que contrariou o exclusivismo do Padroado português, que era comandado pela Companhia de Jesus (ALENCASTRO, 2000, p. 277). A partir da década de 1640, chegaram na África Central os missionários Capuchinhos, de nacionalidade italiana e espanhola. Para Portugal, que ainda estava em guerra com a Espanha, ter missionários espanhóis em suas possessões no ultramar era um grande perigo, pois poderia ser espiões da Coroa espanhola, ou então uma forma dos castelhanos se fazerem presentes para uma possível ocupação. Com o início das missões capuchinhas tanto no Congo como nos sertões de Angola, ficou evidente a falta de compromisso dos Jesuítas na propagação da fé, os mesmos tinham se engajado nos negócios da África central, sobretudo o tráfico de escravos. Em carta ao rei de Portugal, datada de 24 de agosto de 1648, o Padre Nuno da Cunha apontou as dificuldades que os portugueses tinham em manter as suas conquistas, pela falta de missionários, e os que se encontravam na região não exerciam mais a pregação da fé (BRÁSIO, 1952, p. 212). Em carta de 1655, desta vez do Capuchinho Serafim de Cortona, que foi prefeito da missão de Matamba, foi denunciado que o interesse dos Jesuítas no Congo foi pelo fato de possuírem muitos escravos na região, em torno de 2.000, e que isso exigia transações comerciais continuas, esse foi o motivo da Companhia de Jesus não querer outras ordens religiosas na região (ALENCASTRO, 2000, p. 278). Em outra carta do Frei Serafim de Cortona, em 31 de janeiro de 1660, encaminhada a Propaganda Fide (BRÁSIO, 1981, p. 280), o frei se queixou dos problemas de jurisdição envolvendo os jesuítas. Outra denuncia no envolvimento dos Jesuítas no tráfico de escravos para o Brasil foi uma carta do Padre José Maria de Busseto aos Cardeais da Propaganda Fide, datada de 8 de março de 1687 (BRÁSIO, 1985, p. 47-48). 
Portugal estava em uma situação bastante complicada, pois precisava dos missionários para recuperar as alianças no interior, nesse caso os capuchinhos tiveram um grande destaque, principalmente na conversão da rainha Nzinga, e na do Jaga Cassange ${ }^{25}$, onde os lusos recuperaram um grande mercado de escravos no sertão. Apesar da conveniência, a Coroa teve várias restrições na entrada dos capuchinhos nas suas zonas de influências na África central, a prioridade era dos missionários portugueses. A Coroa teve que agir com muita cautela, pois a cultura política lusa favorecia os Jesuítas, pelo fato deles terem dado apoio aos lusos na restauração de 1640.

Foi nesse contexto de intrigas entre as Ordens religiosas que João Fernandes Vieira foi governar Angola. Três dias após a sua posse ${ }^{26}$, Vieira se deparou com uma situação que se estendeu por um bom tempo. Assim que chegou em Luanda, Vieira observou que existia um número grande de animais nas ruas, e que isso trazia maus cheiros e doenças, um caso de abalo a saúde pública. Vieira foi informado que os oficiais da câmara de Luanda tinham proibido que esses animais "sevados" ${ }^{27}$, ficassem soltos nas ruas, justamente para evitar imundices e enfermidades contagiosas. Como a proibição não tinha causado o efeito desejado, Vieira ordenou aos soldados que matassem os animais que se encontrassem nessa situação. No dia 21 de abril de 1658, três soldados vindos de Pernambuco estavam em patrulha e viram 2 ou 3 sevados na rua, e logo foram a captura para matar os animais, negros armados de arco-e-flexa foram evitar a captura dos animais e entraram em conflito com os soldados, deixando-os feridos e um em estado muito grave. Quando soube do que aconteceu, Vieira mandou prender os negros, e se houvesse resistência, os soldados poderiam matalos. Três negros foram presos, e vários outros ficaram ofendendo os soldados. Vieira ficou sabendo logo após a prisão dos negros, que eles pertenciam ao Colégio dos Jesuítas, como também os animais que eles estavam evitando a captura, logo mandou soltar os presos. Quando os jesuítas descobriram o que aconteceu, tiveram o fato como uma grande ofensa. O Reitor do Colégio dos Jesuítas, o Padre Francisco Pinheiro, a qual convocou uma reunião com a Ordem em portas fechadas, executaram no dia 28 do mesmo mês a excomunhão dos mandantes e dos que executaram a ordem de prender os negros, e ainda foi fixado nas igrejas de Luanda a excomunhão, o que foi

25 Foram várias as correspondências de Nzinga solicitando mais missionários capuchinhos para batismo e conversão do seu povo e sobas vassalos. (MONTECÚCCOLO, 1965, p. 339, 343-344). O Frei Serafim de Cortona relatou as mesmas solicitações de Nzinga e tambem do soba Cassange (BRÁSIO, 1981, p. 202-203).

26 José Antonio Gonsalves de Mello afirmou que o acontecido foi no dia 23, cinco dias após a posse (2000, p. 345), mas em um requerimento datado de 15 de setembro de 1659, a informação foi de que o acontecido foi três dias após a posse de 18 de abril de 1658 (BRÁSIO, 1981, p. 260).

27 Tanto José Antonio Gonsalves de Mello (2000, p. 344), quanto Luiz Felipe de Alencastro (2000, p. 277) afirmaram que os animais seriam porcos, mas em nenhum documento analisado se teve essa informação, o que a documentação informou foi que foram animais sevados, e de acordo com o dicionário do início do século XVIII, sevados tanto poderia significar animais gordos, como porcos ou aves, como também poderia significar animais encarniçados, ou doentes (BLUTEAU, 1712, p. 259). 
uma grande ofensa ao governador, pois o mesmo se sentiu escandalizado ${ }^{28}$.

Com a excomunhão, Vieira logo tratou de reverter a situação a seu favor, foi uma boa oportunidade de colocar a autoridade dos jesuítas em xeque. Em carta de Vieira ao Rei, datada de 15 de setembro de 1659 (BRÁSIO, 1981, p. 263-264), ele relatou que consultou sobre o caso alguns juristas e vários doutores teólogos, além de outros religiosos, como o Frei Manoel de Macedo que teve muito prestígio perante a cristandade. Os mesmos disseram que a excomunhão dos jesuítas foi nula e sem efeitos, pois não houve violência nem abuso aos eclesiásticos, e a causa de Vieira era justa, pois não houve excessos de jurisdição. A possibilidade dos capuchinhos terem apoiado Vieira pode ser confirmada por uma carta que ele enviou para a Propaganda Fide, datada de 5 de julho de 1658 (BRÁSIO, 1981, p. 167-168), a qual relatou o acontecido e se queixou dos jesuítas de Luanda, além de ter pedido providências enérgicas contra os excessos por eles cometidos. Não era comum um governador se dirigir a Propaganda Fide para resolver assuntos relacionados aos jesuítas portugueses. Vieira também preparou um dossiê com várias informações sobre a conduta dos jesuítas em Luanda, talvez com ajuda dos capuchinhos, e enviou as informações em carta ao Rei, datada de 5 de novembro de 1658 (BRÁSIO, 1981, p. 179-189). No documento, Vieira explicou que os 2000 cruzados de esmolas dados a Companhia de Jesus por ano não eram mais necessários, deveriam ser investido na fortificação de Angola, pois essas esmolas deveriam ser concedidas apenas para os religiosos que não possuíam bens a qual pudessem se sustentar, e que se dedicavam exclusivamente na propagação da fé, divulgação do evangelho e conversão das almas. Vieira explicou que os jesuítas tinham deixado todas essas obrigações de lado, pois tinham se tornado grandes proprietários, com 50 fazendas nos melhores lugares de Angola, com a posse de 10 mil escravos, e ainda tinham uma receita de 1 milhão de cruzados pelos alugueis das melhores casas de Luanda $^{29}$. Vieira os acusou também de não irem mais aos sertões para as missões evangélicas, os mesmos ficavam na cidade para tratar de seus negócios, principalmente no tráfico de escravos, e também foram acusados de não pagar pelos serviços de alguns pumbeiros ${ }^{30}$. Vieira ainda afirmou a participação dos jesuítas no tráfico, quando disse que são poucos padres para uma quantidade enorme de escravos. O governador de Angola anterior a Vieira, Luis de Sousa Chichorro, já tinha informado algumas irregularidades na conduta dos jesuítas (MELLO, 2000, p. 349), mas foi no

28 O relato detalhado do acontecido se encontra na carta de Vieira ao Rei, datada de 15 de setembro de 1659 (BRÁSIO, 1981, p. 261-265). Vieira tinha mandado a mesma carta no ano de 1658, mas a correspondência foi extraviada por um ataque de piratas. Não se encontrou documentos que pudessem servir como analise da versão dos jesuítas sobre o acontecido.

29 Na relação, de 1760, dos bens confiscados aos jesuítas, depois da expulsão dos mesmos de Portugal e do ultramar, já na sua decadência, ainda tinham em Angola 19 fazendas e 1.080 escravos (MELLO, 2000, p. 349).

30 Agentes na sua maioria formados por mestiços. Os lançados ou pumbeiros trabalhavam negociando com os grandes chefes tribais ou reis africanos. Durante um tempo, internavam-se no interior da África-central, trocavam os escravos por tecidos, vinho e objetos de quinquilharias, voltando com uma centena de escravos para serem negociados com os agentes no litoral africano. 
relato de Vieira que as acusações foram mais contundentes.

No requerimento de 15 de setembro de 1659 (BRÁSIO, 1981, p. 260-261), o dossiê enviado por Vieira foi repetido, e ainda foi acrescentado que os jesuítas tinham criado problemas com outros governadores anteriormente, e os mesmos não respeitavam as devidas jurisdições, querendo governar Angola de acordo com seus interesses. No mesmo documento os jesuítas foram acusados de serem mentirosos e ambiciosos. Ficou claro no documento os conflitos entre o poder espiritual e temporal, a qual a solicitação foi de que os jesuítas não interferissem nos assuntos de governo.

A Coroa ou o Conselho Ultramarino demoraram para tomar as providências com relação ao acontecido, pois em carta ao Rei, de 20 de setembro de 1659 (BRÁSIO, 1981, p. 260-261), Vieira repetiu o dossiê contra os jesuítas, enfatizando ainda mais a participação dos mesmos no tráfico de escravos. Essa foi a maior questão levantada por Vieira, sobretudo pela concorrência aos seus agentes no trato negreiro. Quase um ano depois da ultima carta de Vieira, onde ele não era mais o governador de Angola, e já tinha retornado para Pernambuco, foi que o Conselho Ultramarino deu um parecer sobre o assunto. Talvez fosse uma questão de ordem, dar os pareceres sobre esses tipos de conflitos após o mandado do governador. O Conselho formado pelo Conde de Soure, por Simão de Miranda Henriques, Jerônimo de Melo de Castro, Feliciano Dourado, e Francisco de Valladares Souto Maior, deram parecer favorável a Vieira, em 8 de novembro de 1661 (BRÁSIO, 1981, p. 349-355), a qual relataram ao Rei os acontecimentos, baseado na carta de Vieira de 15 de setembro de 1659. O Conselho informou ao rei, a gravidade da situação por se tratar de um conflito de jurisdição, acusou os padres da Companhia de Jesus de terem incentivado a ousadia dos negros contra os soldados lusos, pois no momento do conflito, testemunhas disseram que os padres mandaram os negros matarem os soldados. Os jesuítas também foram acusados de terem dado privilégios aos negros, o que na visão do Conselho isso foi muito perigoso, pois os negros poderiam se aproveitar disso para ter criado um motim e até mesmo lutar pela autonomia na região. Ainda relataram que Vieira tinha agido no seu direito e tinha feito muito bem em punir os negros rebeldes para evitar qualquer mau exemplo, o Conselho também enviou um parecer dos doutores teólogos que Vieira já tinha exposto anteriormente. Para concluir o caso, o Conselho sugeriu que o novo governador de Angola, André Vidal de Negreiros, punisse os negros rebeldes com mais vigor. E com relação aos jesuítas o Conselho sugeriu retirar as suas ordenações ${ }^{31}$, e ainda enviaram uma

31 As esmolas anuais de 2.000 cruzeiros. 
carta ao ministro do Santo Oficio ${ }^{32}$ explicando o acontecimento e exigindo punições aos jesuítas. O Conselho também relatou conflitos semelhantes no Brasil e em algumas possessões na Ásia. As sugestões do Conselho teve a aprovação do rei D. Afonso VI, a qual tem sua assinatura no documento.

Com a saída da Rainha mãe, D. Luisa de Gusmão, da regência de Portugal, em 1662, e sob a influência do ministro Luis de Vasconcelos Souza, o Conde de Castelo Melhor, D. Afonso VI tomou medidas mais enérgicas sobre o conflito entre Vieira e os jesuítas. O Rei enviou duas cartas no mesmo dia, 9 de dezembro de 1662, uma para o governador de Angola, André Vidal de Negreiros, a qual exigiu que se fizesse uma devassa ao Colégio dos Jesuítas (BRÁSIO, 1981, p. 415-416), e outra carta diretamente ao Reitor do Colégio dos Jesuítas, exigiu respeito aos governadores, enfatizando que a jurisdição eclesiástica não deveria intervir no julgamento real, e os governadores eram representantes desse poder, na mesma carta o rei se mostrou desgostoso com a excomunhão de Vieira pelos padres (BRÁSIO, 1981, p. 417-418).

Esse conflito entre Vieira e os Jesuítas foi um marco que representou o início da diminuição dos privilégios dessa Ordem na capitania de Angola, que foi se consolidar com a expulsão da Companhia de Jesus no reino de Portugal e nas suas possessões no ultramar, em 1759, no governo de D. José, e o ministro Marques de Pombal (MARQUES, 1980, p. 571). Vieira não foi o único problema dos jesuítas, os mesmos tiveram conflitos com outras Ordens religiosas, principalmente os capuchinhos que adquiriram prestígio pelas suas atuações missionárias nos sertões de Angola. A relação entre Vieira e os capuchinhos não tiveram maiores problemas, talvez pelo fato da aliança contra os jesuítas, mas também por um outro interesse em comum, ligar por terra Angola a Moçambique. O prefeito da missão de Matamba levantou a possibilidade de continuar as pregações nos sertões até a outra Costa africana, o que para Vieira foi uma grande oportunidade de ampliar a zona de influência para o tráfico de escravos (BRÁSIO, 1981, p. 212). O próprio Frei capuchinho Cavazzi em sua obra fez vários elogios a Vieira e suas ações como governador (MONTECÚCCOLO, 1965, p. 250-261).

Foi no governo de Vieira que chegou em Angola a Ordem dos Carmelitas Descalços, Talvez com o propósito de equilibrar as forças entre jesuítas e capuchinhos, ou mesmo preencher os sertões de Angola com missionários portugueses, já que os jesuítas não estavam indo mais ao interior. Em Carta regia, de 7 de janeiro de 1659 (BRÁSIO, 1981, p. 206), para a câmara de Luanda

32 A carta é enviada em 14 de outubro de 1662. 
e ao governador, a Rainha exigiu que os colonos oferecessem toda a ajuda necessária aos Carmelitas Descalços, sobretudo na construção da Casa e do Hospício da dita Ordem, e se fosse necessário podiam fazer uso da receita da fazenda real. Com essa mesma preocupação a rainha enviou uma carta diretamente a Vieira (BRÁSIO, 1981, p. 206), para o governador ajudar os carmelitas no que for preciso, afirmando que os mesmos tinham como missão a conversão dos gentios no reino. Os carmelitas foram muito bem recebidos, e Vieira fez questão de repassar isso para a Coroa. Em carta ao Rei, de 15 de novembro de 1659 (BRÁSIO, 1981, p. 277-278), Vieira relatou que os carmelitas estavam bem abrigados e já tinham escolhido o lugar para a construção do hospício, e que não precisou fazer uso da fazenda real, pois criou um novo imposto específico para a Ordem Carmelita. E o mesmo ainda resaltou a necessidade dos carmelitas fazerem missões nos sertões. Provavelmente por influência de Vieira, a câmara de Luanda enviou uma carta ao rei, no mesmo dia que Vieira, deram graças por ter recebido os Carmelitas Descalços (BRÁSIO, 1981, p. 276). Em outra carta datada de 3 de julho de 1660 (BRÁSIO, 1981, p. 292), Vieira fez uma doação de terras virgens aos Carmelitas Descalços, para que os mesmos construíssem o seu convento, financiado pelo imposto criado por Vieira anteriormente. Não se sabe os favorecimentos que Vieira teve da Ordem, mas o fato do mesmo ter feito valer os pedidos da rainha, podem ter lhe dado um prestígio maior perante o reino, o que pode lhe ter favorecido nas várias acusações que foram feitas no fim do governo, quando já tinha retornado para Pernambuco. E com relação aos Carmelitas Descalços, os mesmos ganharam cada vez mais espaço, talvez pelo fato das suas missões no interior, como também pela diminuição de poder dos jesuítas, pois em 4 de abril de 1666, o Rei de Portugal declarou que o cargo de pregador do bispado de Angola deveria ser ocupado por um membro da Ordem dos Carmelitas Descalços (BRÁSIO, 1982, p. 15-16).

\section{Considerações finais: o retorno para Pernambuco}

Em 10 de maio de 1661, chegou em Luanda para tomar posse do governo, André Vidal de Negreiros, parceiro comercial de Vieira, tinha governado Pernambuco durante todo o governo de Vieira em Angola, o que facilitou os negócios no tráfico de escravos entre Luanda e Recife. Vieira passou alguns meses com Negreiros, repassando os acontecimentos e as alianças formadas, bem como os problemas que precisavam ser resolvidos, principalmente a guerra contra o reino do Congo (ALENCASTRO, 2000, p. 287). Vieira deixou para Negreiros a casa em que residiu, com todo o mobiliário, e retornou para Pernambuco na mesma nau que tinha chegado em Angola. Ao chegar em 
Pernambuco, no dia 2 de abril de 1662 (MELLO, 2000, p. 352), Vieira tratou de organizar seus negócios como senhor de engenho e grande comerciante, sempre entrando em contato com seus agentes em Angola, principalmente no governo de Negreiros que foi até 1666.

O Rei, D. Afonso VI, em 1663, determinou que se tirasse a "residência"33 do governo de Vieira em Angola, por conta das várias queixas que tinham feito contra ele no Conselho Ultramarino, todas as queixas foram encaminhadas a Jorge da Silva Mascarenhas (BRÁSIO, 1981, p. 440). A "residência" foi tirada pelo ouvidor-geral de Angola, João de Oliveira de Miranda, sucedido por Antônio de Castro de Sousa. O conselheiro ultramarino, João Falcão de Sousa deu o parecer da devassa em carta ao Rei, datada de 21 de maio de 1665 (MELLO, 2000, p. 353-354), o mesmo relatou que Vieira tinha cometido irregularidades na Fazenda Real, adquirindo lucros injustos. O mesmo sugeriu que o rei mandasse sequestrar os bens de Vieira, bem como prende-lo e leva-lo ao Reino, para ser punido pelos excessos e infortúnios que cometeu, acusou Vieira de não ter cumprido o regimento de Angola, e que usou poderes absolutos contra os soldados da região, e ainda fez de cativos muitos negros livres ${ }^{34}$. A carta ainda informou que Vieira fez um monopólio no fornecimento de sal na região de Benguela, a qual só podia ser comprado pelos seus agentes e por um preço diferenciado ${ }^{35}$. João Falcão ainda sugeriu que Vieira fosse punido para servir de exemplo aos outros governadores. Mesmo com o parecer do Conselho Ultramarino, o rei considerou a "residência" nula, e determinou que se fizesse outra, desta vez com um ouvidor recomendado por ele. Não foi encontrado documentos que fizessem referência a segunda devassa, mas em uma carta régia datada de 25 de abril de 1687, ao ouvidor geral da Capitania de Pernambuco, a qual o rei ordenou que a viúva e os herdeiros de Vieira fizessem cumprir as ações e os direitos sobre a "residência" feita de quando Vieira governou Angola (MELLO, 2000, p. 354-355). E em outra carta regia de 9 de março de 1686, ao provedor da fazenda de Angola, Jerônimo da Veiga Cabral, determinou o sequestro e o leilão dos bens de Vieira em Angola, para pagar as dívidas com a Fazenda Real, e a sentença deveria ser entregue a Vieira ou aos seus herdeiros (MELLO, 2000, p. 355). Em ambas as cartas, Vieira já tinha falecido, sua morte foi em 10 de janeiro de 1681, portanto não tinha como recorrer das ações reais, talvez tudo planejado pela Coroa, pois em vida, Vieira recorreu sempre que pode, como aconteceu em 1669, quando recorreu ao rei a decisão de lhe cobrar

33 Chamava-se assim as informações recolhidas, no local do exercício dos funcionários da Coroa, a respeito da maneira por que tinha procedido nas coisas do seu oficio (MELLO, 2000, p. 353).

34 Estas acusações também se fizeram presentes na acusação de Francisco Sidrales Souto Maior ao rei, desafeto militar de Vieira e que tinha processado o governador por perdas e danos (MELLO, 2000, p. 342).

35 Em carta régia ao governador de Angola André Vidal de Negreiros, o rei perguntou a Negreiros qual a utilidade do percurso entre Luanda e Benguela, que Vieira abriu com custos da Fazenda Real, e quais os benefícios dessa empreitada para a Coroa (BRÁSIO, 1981, p. 466). 
vencimentos excessivos, relacionados as esmolas, de quando foi governador de Angola, Vieira escreveu ao rei um dossiê sobre os seus 39 anos de serviços prestados para a Coroa, e ainda justificou as esmolas, que foram para as Ordens e soldados que realmente precisavam (MELLO, 2000, p. 356). O Conselho deu parecer favorável a Vieira e o rei mandou revogar a cobrança da dívida.

Uma última relação de Vieira com Angola registrada na documentação, foi a sua ajuda a um pedido de socorro do governador de Angola, Francisco de Távora, em 1671, para combater sobas rebeldes no Pungo Andongo, região próxima de onde ficava o reino do Jaga Cassange. A solicitação de Francisco de Távora aos governadores no Brasil, não tinha autorização régia, mas talvez pelo interesse em renovar sua influência no tráfico negreiro, Vieira junto com o governador de Pernambuco, Fernão de Sousa Coutinho, enviou para Angola, 200 infantes e mais alguns cavalos, de suas próprias finanças ${ }^{36}$.

Foi justamente no governo de Vieira em Angola, através de suas práticas políticas e militares, adquiridas em Pernambuco, que os números do tráfico de escravos para o Brasil aumentou consideravelmente. De 1626 a 1650, tem uma estimativa de que chegaram no Brasil 50 mil escravos vindos da África, já de 1651 a 1675, a estimativa aumentou para 185 mil escravos, e a partir de 1675 os números só aumentaram, chegando na estimativa do início do século XVIII em uma média de 16 mil escravos por ano (ALENCASTRO, 2000, p. 69). Esse tráfico de humanos, em que africanos migraram forçadamente para o Brasil, formou uma circularidade cultural que se tornou a base da formação da sociedade brasileira.

\section{REFERÊNCIAS}

ALENCASTRO, Luiz Felipe de. O trato dos viventes: Formação do Brasil no Atlântico Sul. São Paulo: Companhia das letras, 2000.

Arquivos de Angola. Série 1, volume 2, número 9. Luanda: Conselho Superior de Estatística, 1936.

BLUTEAU, Pe. Raphael. Vocabulário português e latino. Coimbra: Collegio das Artes da Companhia de Jesus, 1712.

BRÁSIO, Padre Antonio. Monumenta Missionária Africana. Série 1, Volume 10. Lisboa: Agência Geral do Ultramar, 1965.

36 Consulta do Conselho Ultramarino, datada de 15 de junho de 1671 (AHU-ACL-CU-015, Cx. 10, D. 921). 
BRÁSIO, Padre Antonio. Monumenta Missionária Africana. Série 1, Volume 12. Lisboa: Academia Portuguesa da História, 1981.

BRÁSIO, Padre Antonio. Monumenta Missionária Africana. Série 1, Volume 13. Lisboa: Academia Portuguesa da História, 1982.

BRÁSIO, Padre Antonio. Monumenta Missionária Africana. Série 1, Volume 14. Lisboa: Academia Portuguesa da História, 1985.

CADORNEGA, Antonio de Oliveira de. História geral das guerras angolanas, Tomo II. Lisboa: Agência geral das colônias, 1940.

CORRÊA, Elias Alexandre da Silva. História de Angola. Volume 1. Lisboa, 1937.

CUNHA MATOS, Brigadeiro R. J. da. Compêndio histórico das possessões de Portugal na África. Rio de Janeiro: Arquivo nacional. 1963.

FERREIRA, Roquinaldo. O Brasil e a arte da guerra em Angola. Estudos históricos, Rio de Janeiro, n⿳30, janeiro-junho de 2007.

MARQUES, A. H. de Oliveira. História de Portugal. V-1. Lisboa: Palas editora, 1980.

MELLO, José Antônio Gonsalves de. João Fernandes Vieira: Mestre-de-campo do Terço de Infantaria de Pernambuco. Lisboa: Comissão Nacional para as Comemorações dos Descobrimentos Portugueses, 2000.

MONTECÚCCOLO, Pe. João António Cavazzi de. Descrição histórica dos três reinos do Congo, Matamba e Angola. Volume 2. Lisboa: Junta de Investigações do Ultramar, 1965.

Fontes manuscritas do Arquivo Histórico Ultramarino

\author{
AHU-ACL-CU-015, Cx. 6, D. 497. \\ AHU-ACL-CU-015, Cx. 7, D. 576. \\ AHU-ACL-CU-015, Cx. 7, D. 620. \\ AHU-ACL-CU-015, Cx. 10, D. 921.
}

